\title{
Anti-Inflammatory Activities of Marine Algae in Neurodegenerative Diseases
}

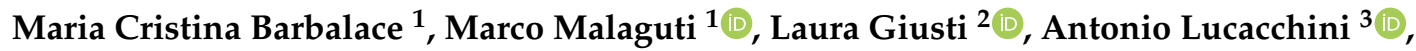 \\ Silvana Hrelia $1, * \mathbb{D}$ and Cristina Angeloni ${ }^{2, * \mathbb{D}}$ \\ 1 Department for Life Quality Studies, Alma Mater Studiorum-University of Bologna, 40126 Bologna, Italy; \\ maria.barbalace2@unibo.it (M.C.B.); marco.malaguti@unibo.it (M.M.) \\ 2 School of Pharmacy, University of Camerino, 62032 Camerino, Italy; laura.giusti@unicam.it \\ 3 Department of Clinical and Experimental Medicine, University of Pisa, Pisa 56126, Italy; \\ antonio.lucacchini@gmail.com \\ * Correspondence: silvana.hrelia@unibo.it (S.H.); cristina.angeloni@unicam.it (C.A.)
}

Received: 31 May 2019; Accepted: 19 June 2019; Published: 22 June 2019

\begin{abstract}
Neuroinflammation is one of the main contributors to the onset and progression of neurodegenerative diseases such as Alzheimer's and Parkinson's diseases. Microglial and astrocyte activation is a brain defense mechanism to counteract harmful pathogens and damaged tissues, while their prolonged activation induces neuroinflammation that can trigger or exacerbate neurodegeneration. Unfortunately, to date there are no pharmacological therapies able to slow down or stop the progression of neurodegeneration. For this reason, research is turning to the identification of natural compounds with protective action against these diseases. Considering the important role of neuroinflammation in the onset and development of neurodegenerative pathologies, natural compounds with anti-inflammatory activity could be good candidates for developing effective therapeutic strategies. Marine organisms represent a huge source of natural compounds, and among them, algae are appreciated sources of important bioactive components such as antioxidants, proteins, vitamins, minerals, soluble dietary fibers, polyunsaturated fatty acids, polysaccharides, sterols, carotenoids, tocopherols, terpenes, phycobilins, phycocolloids, and phycocyanins. Recently, numerous anti-inflammatory compounds have been isolated from marine algae with potential protective efficacy against neuroinflammation. This review highlights the key inflammatory processes involved in neurodegeneration and the potential of specific compounds from marine algae to counteract neuroinflammation in the CNS.
\end{abstract}

Keywords: neuroinflammation; neurodegeneration; algae; seaweeds; neurodegenerative diseases

\section{Introduction}

Neurodegeneration refers to a progressive and permanent loss of neurons in specified regions of the brain and spinal cord. It is the pathological condition that characterizes many neurodegenerative diseases, including Alzheimer's disease (AD), Parkinson's disease (PD), multiple sclerosis (MS), Huntington's disease (HD), amyotrophic lateral sclerosis (ALS) [1], and traumatic brain injury (TBI) [2]. The main cellular and molecular events that trigger neurodegeneration are oxidative stress, abnormal protein deposition, damaged mitochondrial function, induction of apoptosis, impairment of proteostasis, and neuroinflammation [3]. Since the first identification of the main neurodegenerative disorders, research on the molecular mechanisms underlying these pathologies has focused on major anatomical changes such as neuronal loss and protein aggregation [4]. In recent years, more and more studies have highlighted the key role of the immune system in the initiation and progression of neurodegeneration $[5,6]$ due to changes in cytokine signaling, immune cell proliferation and 
migration, altered phagocytosis, and reactive gliosis as common features of neurodegeneration [4]. Neuroinflammation, or, more specifically, the activation of the neuroimmune cells microglia and astrocytes into proinflammatory states, is an effective endogenous defense that protects the central nervous system (CNS) against microorganisms and injuries. It is usually a positive mechanism that aims to eliminate threats and restore homeostasis [7]. However, prolonged neuroinflammatory events can lead to a series of events that conclude with progressive neuronal damage that characterizes many neurodegenerative disorders [8]. The glial cells, microglia and astrocytes, have a pro- and anti-inflammatory role and are involved in different functions under physiological and disease conditions, such as phagocytosis, steroid release, free radical reduction, and cellular repair [9]. Glial cells exert a proinflammatory action through the production of cytokines and reactive oxygen species (ROS) that lead to synaptic dysfunction, loss of synapses, and neuronal death resulting in CNS injury. Until now, most research has been focused on microglial cells as key actors of neuroinflammation in neurodegeneration, but recently new scientific evidence has shown the important contribution of astrocytes to the inflammation that characterizes neurodegenerative diseases [10-12]. Unfortunately, to date there are no pharmacological therapies able to slow down or stop the progression of these devastating pathologies. For this reason, research is turning to the identification of natural compounds with protective action against these diseases. Considering the important role of neuroinflammation in the onset and development of neurodegenerative pathologies, natural compounds with anti-inflammatory activity could be good candidates to develop effective therapeutic strategies. Marine organisms represent a huge source of natural compounds, some of which have different structural characteristics from those of terrestrial origin. Marine-derived natural compounds could produce different pharmacological effects, like anti-diabetic [13], anti-inflammatory [14], antioxidant [15], anticancer [16], and anti-obesity [17] activities, and open the way for the development of new drugs [18]. Of note, seven marine-derived natural compounds have been approved for clinical use [19].

Among marine organisms, algae are one of the most valuable resources of the sea. Epidemiological studies comparing Japanese and Western diets show an association between algae consumption and a lower incidence of chronic degenerative diseases [20]. Algae are appreciated sources of important bioactive components such as antioxidants, proteins, vitamins, minerals, soluble dietary fibers, polyunsaturated fatty acids, polysaccharides, sterols, carotenoids, tocopherols, terpenes, phycobilins, phycocolloids, and phycocyanins [20]. Recently, Fernando et al. [21] summarized the latest knowledge about the potential anti-inflammatory activity of marine algae derivatives, evidencing their potential protective efficacy against neuroinflammation too. In particular, marine algae have been shown to counteract neuroinflammation by acting at different cellular levels: inhibiting pro-inflammatory enzymes such as COX-2 and iNOS [22], modulating MAPK pathways [23], and NK-kB activation [24], among others. Currently there are no clinical trials on the effects of marine algae against neuroinflammation but, given their important biological activities, as demonstrated by in vitro and animal studies, we believe that they will be carried out in the near future. Moreover, as anti-inflammatory drugs can trigger complications and important side effects [25,26], identifying novel anti-inflammatory agents from marine algae could be a valid solution to overcome this problem. In fact, anti-inflammatory natural compounds have been demonstrated to be safe thanks to their long use in folk medicine [27].

This review highlights the key inflammatory processes involved in neurodegeneration and the potential of marine algae and specific compounds from marine algae to counteract neuroinflammation in the CNS. The most recent and relevant results on the promising anti-inflammatory activities of marine algae related to neuroprotection have been selected.

\section{Methods}

A PubMed search was conducted. The combinations of terms that we used for this search were "marine algae and neuroinflammation," "marine algae and clinical studies," "marine algae 
and inflammation," "marine algae and toxicity," and "marine algae." We also combined the terms marine algae and neuroinflammation with fucosterol, phlorotannins, astaxanthin, polysaccharides, glycoprotein, chlorophyll, lutein, zeaxanthin, violaxanthin, neoxanthin, or $\beta$-carotene. No restrictions were placed on the date of the articles or the language of publication. Studies with a clearly described methodology were included.

\section{Molecular Mechanisms of Neuroinflammation}

Neuroinflammation is a defense process aimed to protect both the brain and the spinal cord from tissue damage or pathogen invasion [8]. Generally, inflammatory processes involve numerous cellular types and mediators with the aim of separating, via the formation of a glial scar, damaged tissue from healthy tissue [28]. When an insult occurs at brain level, the immune response is mediated through cross-talk between the CNS and the periphery. In fact, due to inflammation, blood-brain barrier (BBB) permeability is increased and leucocytes can infiltrate into the CNS [9].

At the brain level, microglia, astrocytes, and oligodendrocytes constitute the neuroglial cells [29]. Microglia have been demonstrated to be derived from primitive macrophages [30] and are now considered the resident immune system of the brain [31]. In non-activated conditions, microglia contribute to brain homeostasis [32] by modulating neuronal survival and maintenance thanks to the ability to release neurotrophic factors such as basic fibroblast growth factor and nerve growth factor (NGF) [33]. Acting as immune cells, microglial cells are also responsible for the phagocytosis of cell debris and contribute to the apoptosis of defective cells [34,35]. More recently, astrocytes, which are known to be involved in CNS homeostasis by sustaining synapse plasticity, have also been demonstrated to participate in protective signaling pathways such as those modulated by glycoprotein gp130, which is crucial for glial cells' survival [36], and by the transforming growth factor beta (TGF $\beta$ ), whose signaling has been shown to exert immunosuppressive effects and to inhibit nuclear factor $\mathrm{kB}$ (NF-kB) nuclear translocation [37].

Beside their neuroprotective properties, the microglia supervise the brain environment by modulating the immune functions in response to tissue damage, degeneration, and pathogen infections [38]. Their activation can be triggered by different stimuli such as lipopolysaccharide (LPS), a well-known toll-like receptor (TLRs) ligand [39], and they represent the first line of defense against infections [40]. Microglia activation results in both morphological and biochemical changes: cells lose their shape and begin to secrete inflammatory biomarkers such as cytokines, eicosanoids, nitric oxide, and ROS [41,42].

Even though neuroinflammation does not usually trigger neurodegenerative diseases, it is directly involved in neuronal dysfunctions and contributes to neuronal death and to neurodegenerative disease progression [43]. In fact, diseases such as PD, AD, ALS, and MS, as well as ischemia and TBI, are associated with chronic inflammation and long-lasting microglia activation [44]. Such chronic inflammatory states result in an abnormal increased cytokine levels [45], the production of neurotoxic mediators, and oxidative stress that triggers a pro-inflammatory cycle [46] and amplifies degenerative processes such as abnormal protein deposition, mitochondrial dysfunction, and BBB permeability impairment [44,47,48].

Chronic inflammation in neurodegenerative diseases is sustained by TLRs activation at the glial level [49]. Among TLRs, TLR4 is the most expressed in microglia [50]; its activation has been demonstrated to be responsible for chronic inflammation in $\mathrm{AD}$, where $\mathrm{A} \beta$-oligomers interact with TLR4 and increase its expression [51,52], and in PD, where TLR4 protein expression is also increased in both in vitro and in vivo model systems [53]. Moreover, TLR4 has been found to be responsible for inflammation in spinal cord injury and stroke [54]. TLR4 activation triggers two different downstream proinflammatory signaling pathways, leading to cytokine expression. Among these pathways, the phosphoinositide 3-kinase/protein kinase B (PI3K/Akt) pathway, mammalian target of rapamycin (mTOR) activation, and mitogen-activated protein kinases cascades (MAPKs) are the main ones involved and lead to NF- $\mathrm{KB}$ activation $[7,55,56]$. Once activated, PI3K triggers 
Akt phosphorylation, which in turn activates mTOR. The mTOR pathway plays a pivotal role in the regulation of NF- $\mathrm{kB}$ and inflammation [57]. NF- $\mathrm{kB}$ signaling is considered particularly important in every neuroinflammation-related disease. After initial TLR4 activation, the sequence of events that leads to the translocation of NF- $\mathrm{KB}$ to the nucleus includes the activation of the protein IKB kinase, phosphorylation of the IкB inhibitory protein, and the consequent release of active NF- $\kappa B$ [58]. As a dimer, NF- $\mathrm{kB}$ translocates to the nucleus, where it activates the transcription of its target genes such as inducible nitric oxide synthase (iNOS), cyclooxygenase (COX2), tumor necrosis factor alpha (TNF- $\alpha$ ), interleukin (IL)- 6 , and IL-1 $\beta$ by binding to p65-responsive element [56]. During neuroinflammation, NF- $\mathrm{KB}$ signaling is also stimulated in astrocytes [59], where its translocation to the nucleus and the subsequent cytokines expression is triggered by IL-17-receptor [60] and lactosyl ceramide, a lipid mediator produced by astrocytes [61]. Astrocytes' contribution to neuroinflammation and neurotoxicity has, thus, been demonstrated in models of different neurodegenerative diseases such as brain injury [62] and spinal cord and nerve injury [63,64], where NF-kB inactivation resulted in positive outcomes.

MAPKs are proteins involved in the regulation of multiple cellular functions. In particular, they are involved in the regulation of apoptosis, cell differentiation, and proliferation.

In activated microglia, increased signaling of p38 MAPK and c-Jun N-terminal kinases (JNK) has been described [65]. These MAPKs induce, through the transcription factor activating protein-1 (AP-1), the transcription of proinflammatory genes such as COX2, TNF- $\alpha$, and IL- 6 . The involvement of 38 and JNK signaling in the LPS-activated MG6 microglial cell line has recently been confirmed, showing that LPS treatment strongly induces phospho-p38/p38 and phospho-JNK/JNK ratio, the AP-1 translocation to the nucleus, iNOS protein expression, and NO production [65].

PI3K/Akt and MAPK are not the only pathways involved in neuroinflammation; the Janus Kinase/Signal Transducers and Activators of Transcription (JAKs/STATs) signaling pathway represents a further pathway able to trigger inflammation in the CNS [66]. Several cytokines trigger this pathway by binding their specific receptors and promoting JAK kinase activity, both in microglia and astrocytes. Once activated, JAK phosphorylates STAT, which dimerizes and translocates to the nucleus, where it promotes the expression of cytokine-responsive genes. At least four JAK and seven STAT proteins have been identified [67]. Specific combinations of JAKs and STATs are involved in the response to different cytokines, allowing each cytokine to transduce its own message [66]. JAKs/STATs are involved in the inflammatory response occurring in most neurodegenerative diseases. In MS, endoplasmic reticulum stress induces astrocyte activation through JAK1/STAT3 signaling [68]. IL-6 and IFN- $\gamma$, two major activators of JAKs/STATs signaling, are elevated in PD [69]; moreover, in primary microglial cell culture it has been demonstrated that the inhibition of JAK $1 / 2$ prevents the release of NO, TNF- $\alpha$, and IL-1 $\beta$ induced by $\alpha$-synuclein treatment [70,71].

Besides classical inflammatory pathways, non-classical pathways, such as the Hippo pathway, have been related to neuroinflammation and in particular to astrocyte activation [72]. In its typical sequence of events, the Hippo pathway involves numerous kinases such as Mst 1/2, Sav1, and Last 1/2. Last $1 / 2$ phosphorylates and thus inactivates by proteasomal degradation or cytoplasmic retention, two transcription factors: YAP and TAZ. When dephosphorylated YAP and TAZ migrate to the nucleus, where they promote the expression of downstream genes [73]. YAP has been found to be highly expressed in astrocytes and its deletion induced astrocytic activation in both cell cultures and in vivo studies [72]. In astrocytes, IFN $\beta$ induced YAP activation, which, in turn, promoted the expression of the suppressor of cytokine signaling 3 (SOCS3), a negative regulator of JAK-STAT. In fact, YAP(-/-) astrocytes showed hyperactivation of the JAK-STAT pathway and astrocyte activation [72].

Neuroinflammation represents a crucial aspect of neurodegenerative disease progression. Targeting neuroinflammatory pathways seems to be a promising strategy to counteract neurodegenerative diseases. As different pathways are involved in the onset of neuroinflammation, compounds with different molecular targets are the best candidates to fight this condition. On these bases, beside drug development, the study of natural bioactive compounds, thanks to their varied and complex structures, can help with the identification of effective anti-inflammatory agents. 


\section{Marine Algae}

Algae are photosynthetic eukaryotic organisms that present a complex and controversial taxonomy. More than 20,000 species of algae have been identified, and on the basis of their size they are divided in macroalgae (seaweeds) and microalgae. Macroalgae are multicellular marine plants, while microalgae are small unicellular or simple multicellular species [74]. Marine macroalgae can be classified into three classes according to their pigments: Brown (Phaeophyta) Green (Chlorophyta), and Red (Rhodophyta). The pigments responsible for the algae's color are: fucoxanthin (Phaephyta); chlorophyll $a, b$, lutein, zeaxanthin violaxanthin neoxanthin, and $\beta$-carotene (Chlorophyta); phycobilliproteins and lutein, zeaxanthin, and $\beta$-carotene (Rhodophyta). The classification of microalgae is extremely complex considering the thousands of species present even in small areas of water.

Microalgae are classified into groups based on different characteristics: pigment composition, morphological variations (rounded, oval, cylindrical, and fusiform cells), the presence of thorns, cilia, flagella etc. In addition, they can be classified based on their sizes: picoplankton $(0.2-2 \mu \mathrm{m})$, nanoplankton $(2-20 \mu \mathrm{m})$, and microplankton $(20-200 \mu \mathrm{m})$. Recently, Corrêa et al., at the 16th IEEE International Conference on Machine Learning and Applications in 2017, proposed a deep learning technique to solve the problem by using as input low-resolution images [75].

Marine algae are composed of various substances: carbohydrates, lipids, proteins, amino acids, vitamins, minerals, and secondary metabolites such as phytosterols and polyphenols [76]. The chemical composition of macroalgae is considerably different between species and dependent on the season (sunlight), habitat (salinity, depth in the sea), and environmental conditions.

\subsection{Carbohydrates}

Among the various components, carbohydrates are the most abundant constituents of marine algae. Moreover, polysaccharides are usually the major component of red, green, and brown algae $[77,78]$, and monosaccharides and oligosaccharides are also present. The storage polysaccharide is laminarin in brown algae and floridean in starch (more branched than amylopectin) in green and red algae. Algae cell walls are characterized by the presence of uncommon polysaccharides that can be sulfated, acetylated, etc. Marine algae carbohydrates are promising compounds in various fields, such as food, pharmaceutical, and biomedical. Noteworthy therapeutic applications are due to their antiviral, antibacterial, and antitumoral activities, antioxidant, antilipidemic, and antiglycemic properties, and anti-inflammatory and immunomodulatory characteristics. In particular, alginate-derived oligosaccharides inhibit neuroinflammation [79]. Laminarin (a polysaccharide composed of $(1,3)$ - $\beta$-D-glucan with $\beta(1,6)$ branching), particularly abundant in Laminaria species, has been demonstrated to possess antibacterial and chemopreventive activities, together with prebiotic activity [80], important in modulating gut microbiota, which in turn can regulate neuroinflammation [81]. Algae polysaccharides have been also utilized in the cosmeceutical industries due to their chemical and physical properties exhibiting potential benefits for skin [82].

Table 1 shows the different carbohydrates of brown, green, and red macroalgae. The oligosaccharides derived from polysaccharides are also important. They are produced by chemical or enzymatic hydrolysis and present numerous activities such as antioxidant, anti-inflammatory, and anti-melanogenic [83-87]. Microalgae also produce polysaccharides, and release in particular sulfated polysaccharides (carrageenan, ulvan, and fucoidan) [88-90]. Polysaccharides found in the cell wall vary among microalgae genera and species. Microalgae present an advantage with respect to macroalgae because they are easy to grow and culture and do not depend on the climate or season. 
Table 1. Carbohydrates in marine algae.

\begin{tabular}{cccc}
\hline Carbohydrates & Brown Macroalgae & Red Macroalgae & Green Macroalgae \\
\hline monosaccharides & $\begin{array}{c}\text { glucose, galactose, } \\
\text { xylose, fucose, uronic } \\
\text { acid, glucuronic acid } \\
\text { mannuronic acid, } \\
\text { guluronic acid }\end{array}$ & $\begin{array}{c}\text { glucose, galactose, } \\
\text { mannose }\end{array}$ & $\begin{array}{c}\text { glucose, mannose, xylose, } \\
\text { rhamnose, glucuronic acid, } \\
\text { uronic acid }\end{array}$ \\
polysaccharides & $\begin{array}{c}\text { laminarin alginate, } \\
\text { fucoidan (sulphated), } \\
\text { cellulose, mannitol }\end{array}$ & $\begin{array}{c}\text { agar (sulfated), floridean } \\
\text { starch, cellulose, lignin, } \\
\text { funoran }\end{array}$ & $\begin{array}{c}\text { ulvan (sulfated), mannan, } \\
\text { galactans (sulfated), } \\
\text { xylans, floridean starch, } \\
\text { cellulose, lignin }\end{array}$ \\
\hline
\end{tabular}

To date the ability of algae-derived polysaccharides to counteract neuroinflammation has not yet been fully explored.

\subsection{Lipids}

Algae contain different types of lipid phospholipids, non-polar glycerolipids, glycolipids, betaine lipids, and some unusual lipids, e.g., sulfolipid (sulfoquinovosyldiacylglycerol) sterols [91].

Marine macroalgae have a low lipid content but the proportion of long-chained polyunsaturated fatty acids (PUFA) is relatively high. In macroalgae, PUFAs are represented by omega- 3 and omega- 6 fatty acids. The content of PUFAs is generally higher in those living in cold water. Eicosapentaenoic acid (EPA) is the principal fatty acid. PUFAs have health benefits: they regulate blood clotting and blood pressure and develop functions of the brain and nervous systems [92,93]. They also decrease the risk of many chronic diseases such as arthritis, diabetes, and obesity [94,95], and regulate the signaling of microglia, mostly in the context of neuroinflammation and behavior [93].

Sterols. Among macroalgae, cholesterol is the most representative sterol in all the red algae; fucosterol, which has anti-inflammatory activity, is the chief sterol in brown algae [96], and in green algae the dominant sterol is isofucosterol clionasterol. Microalgae are characterized by the presence of unusual dihydroxysterols, pavlovols, crinosterols, and stigmasterols. It has been proposed that sterols, due to their ability to cross the blood-brain barrier, can prevent neuroinflammation $[97,98]$, but there are few reports of the neuroprotective activities of algae-derived phytosterols.

\subsection{Proteins and Amino Acids}

Macroalgae and microalgae have been used as a source of human nutrition for thousands of years by some indigenous populations. This is due to their significant protein content, which is even greater than some ground plant sources. Algae proteins are rich in aspartic and glutamic acid, the latter contributing to the typical taste (umami). Green macroalgae, and especially red macroalgae, have a higher protein content than brown macroalgae. Macroalgae also contain a number of bioactive amino acids and peptides (e.g., taurine, carnosine, and glutathione and mycosporine-like) [99] that have been demonstrated to exert antioxidant and antiapoptotic effects in the rat brain [100]. Lectins are a group of glycoproteins isolated from algae [101] that present several properties including anti-inflammatory [102,103] antibiotic, cytotoxic, mitogenic, antinociceptive, and anti-viral due to their ability to bind to specific glycan structures [104]. Marine algae, with their high protein content, are now considered a precious source of bioactive peptides, obtained after enzymatic digestion, with considerable health potential. These biopeptides have been demonstrated to exhibit antioxidant, anticancer, antihypertensive, antiatherosclerotic, and immunomodulatory activities [105]. In the future it is desirable that research address the potential neuroprotective role of these biopeptides, elucidating their mechanism of action. 


\subsection{Phenols}

Phenolic compounds are a class of chemical compounds characterized by hydroxyl groups directly attached to aromatic hydrocarbon rings. The simplest is composed of one aromatic ring and is called phenol. Phenolic compounds can be single phenols or polyphenols, depending on the number of phenol units in the molecule.

Phenols are largely represented in all the organisms belonging to the Plant kingdom; however, the phenols present in marine algae are different to those produced by terrestrial plants [104].

The best known polyphenols in marine algae are phloroglucinols and phlorotannins. Phlorotannins can be classified into subclasses: eckols, fuhalols, fucophlorethols, phlorethols, fucols, and ishofuhalols.

The largest proportion of phenolic compounds is in green and red algae (bromophenols, phenolic acids, and flavonoids). Phlorotannins are found only in marine brown algae $[106,107]$.

Phenols and polyphenols from marine algae have attracted much attention for their anticancer, antioxidant, antimicrobial, and anti-inflammatory activities [108]. To, date several mechanisms behind microglial activation have been reported (see Section 3), and research is moving towards the discovery of alternative anti-inflammatory compounds from natural renewable sources that could potentially counteract neuroinflammation and, therefore, neuronal injury in neurodegenerative diseases, characterized by complex and deeply related phenomena. Marine algae rich in phenols are good candidates for potential application in the nutraceutical sector.

\subsection{Isoprenoids}

Carotenoids and terpenoids are two important classes of isoprenoids belonging to the marine algae. Carotenoids contains eight isoprene units, while terpenoids contain five isoprene units.

The carotenoids that consist of only hydrocarbons are carotenes, while those with oxo, hydroxyl, or epoxy groups are called xanthophylls. The most diffuse carotenoids in marine algae are: $\beta$-carotene, fucoxanthin, astaxanthin, canthaxanthin, and lutein. Fucostantin is mostly present in brown algae and in planktonic microalgae, while $\beta$-carotene is predominant in green microalgae $[109,110]$.

The potential health-promoting effects of these carotenoids are: antioxidant activity, anti-inflammatory effects, anticancer activity anti-obese effect, antidiabetic activity, hepatoprotective effect, antiangiogenic effect, and cerebrovascular protective effect [111-113]. In particular, fucoxanthin has been demonstrated to decrease inflammation and oxidative damage [114] and astaxanthin has been demonstrated to decrease the expression of IL-6 in activated microglial cells [115], all factors implicated in the pathogenesis of neurodegenerative diseases.

Brown macroalgae are considered one of the principal source of biologically and ecologically relevant terpenoids, mainly diterpenes and meroditerpenes [116]. In Sargassum, meroterpenoids prevail, in particular sargachromenol, which presents anti-inflammatory and neuroprotective effects. Also, green algae are a source of terpenes, in particular the genus Caulerpa, which is represented by about 60 species living in tropical and subtropical waters that biosynthesize acyclic and monocyclic sesqui- and diterpenes [117] with neuroprotective activities.

\section{Marine Algae and Neuroinflammation}

As previously mentioned, activated microglia are a critical modulator of the neuroinflammation process, triggering a self-feeding loop with the neighboring astrocytes through the release of pro-inflammatory cytokines, including TNF- $\alpha$ and IL-1 $\beta$ [118]. In this context, a persistent and unrestrained neuroinflammatory loop harms neuronal cells and can promote neurodegenerative diseases [119]. Recent years have been characterized by a huge boost in nutritional research to discover natural compounds with anti-inflammatory properties and potential neuroprotective capacity. Marine algae have been part of a healthy diet in East Asia for centuries and represent a rich reservoir of structurally different bioactive compounds with great potential for pharmaceutical applications. 
Increasingly, reports have shown the anti-inflammatory action of marine algae [120], as well as of their major components such as phlorotannins and pigments [121-123].

The methanol extract of Ulva conglobata, a green alga consumed as a marine vegetable, has been demonstrated to possess anti-inflammatory potential [22]. In particular, the extract was tested in hippocampal neuronal HT22 cells and microglial BV2 cells. In HT22 cells, 40 and $50 \mu \mathrm{g} / \mathrm{mL}$ Ulva conglobata extract was able to significantly restore cellular viability compared to glutamate-treated cells. Moreover, Ulva conglobata extract effectively suppressed IFN- $\gamma$-induced microglial activation, and $50 \mu \mathrm{g} / \mathrm{mL}$ inhibited NO release and reduced the expression of iNOS and COX-2 enzymes. Kim et al. [124] found that the hexane fraction of brown seaweed Myagropsis myagroides ethanolic extract exhibits the highest anti-inflammatory activity among different solvent fractions. In LPS-stimulated BV-2 cells, $25 \mu \mathrm{g} / \mathrm{mL}$ Myagropsis myagroides extract had the potential to revert the induction of pro-inflammatory mediators such as NO, $\mathrm{PGE}_{2}$, and the cytokines IL- 6 and TNF- $\alpha$ through the prevention of NF-KB nuclear translocation and MAPKs phosphorylation. Surprisingly, they did not identify the active compound responsible for these effects. Meanwhile, another report from the same authors suggested that the anti-inflammatory activity of Myagropsis myagroides ethanolic extract in LPS-stimulated BV-2 cells could be completely ascribed to the presence of sargachromenol [125]. A study assessed the anti-neuroinflammatory capacity of three extracts obtained from Malaysian seaweed: Padina australis, Sargassum polycystum, and Caulerpa racemosa [126]. All the extracts reduced the elevation of inflammatory mediators like NO, TNF- $\alpha$, IL-6, and IL-1 $\beta$, with the brown seaweeds (Padina, Sargassum) showing stronger inhibitory activity compared to the green seaweed (Caulerpa).

The so-called "cholinergic hypothesis" suggests a correlation between memory impairment in $\mathrm{AD}$ and the reduction of neurotransmitter acetylcholine [127]. The preservation of acetylcholine levels could be useful in view of a multitarget therapy. Fucosterol, a sterol mainly found in brown algae including Padina australis, was isolated to investigate its cholinesterase and inflammatory inhibitory properties [128]. It was observed that fucosterol inhibits acetylcholinesterase (AChE) and butyrylcholinesterase (BChE), both responsible for acetylcholine hydrolysis, and significantly prevents the production of pro-inflammatory mediators in LPS-induced C8-B4 microglial cells and in A $\beta$-induced BV-2 microglial cells.

Ecklonia cava, an edible brown alga used for the production of food ingredients, animal feed, and fertilizers, has been shown to possess anti-inflammatory activity $[129,130]$.

Three of the major phlorotannins that can be found in Ecklonia cava eckol, dieckol, and 8,8'-bieckol, were investigated for their protective effects against $\mathrm{A} \beta_{25-35}$-induced neuroinflammatory damage in PC12 cells [130]. The results indicated that all phlorotannins tested possess antioxidant and protective effects against $A \beta$ damage, while dieckol has the strongest ability to combat apoptosis and $\mathrm{Ca}^{2+}$ overload and more effectively inhibits the increase of inflammatory markers and the protein levels of $\mathrm{p} 65$, the best studied NF- $\mathrm{kB}$ subunit. Therefore, the neuroprotective property of dieckol with a diphenyl ether linkage was greater than that of $8,8^{\prime}$-bieckol with a biaryl linkage, although these two compounds are both dimers of eckol.

These data were further confirmed by Jung et al. [129], who isolated dieckol from Ecklonia cava extract, reporting its potential as an anti-inflammatory agent by reducing the release and stimulation of pro-inflammatory cytokines and enzymes together with an intracellular scavenging activity. Also, a component from Ecklonia stolonifera, phlorofucofuroeckol B, was identified as a potent suppressor of inflammation, inhibiting I $\kappa \mathrm{B}-\alpha / \mathrm{NF}-\mathrm{KB}$ and Akt/ERK/JNK pathways [23]. A study conducted by Kim et al. [131] demonstrated, for the first time, that floridoside, a natural glycerol galactoside from the red alga Laurencia undulata, possesses the potential to counteract the neuronal damage induced by neuroinflammation in vitro, preventing ROS and NO overload due to iNOS and COX-2 overexpression. Among algae pigments, fucoxanthin is one of the main carotenoids found in brown algae [132]. In an $\mathrm{A} \beta_{42}$-induced microglial activation model, fucoxanthin significantly reduced the rates of inflammatory and oxidative damage, protecting DNA from oxidation and attenuating the increasing of inflammatory enzymes [114]. Astaxanthin, a red carotenoid pigment, occurs naturally in plants and marine seaweeds, 
but also in shellfish and crustaceans [133]. It has been shown to possess a variety of pharmacological effects, including anti-inflammatory and antioxidative activity [133-136].

Increasing evidence correlates a neuronal inflammation status with the development of depression [137,138]. In a rat model of LPS-induced depressive-like behaviors, $80 \mathrm{mg} / \mathrm{kg}$ astaxanthin had an antidepressant-like effect due to the restoration of LPS-induced alterations of brain inflammatory markers (i.e., IL-1 $\beta, \mathrm{IL}-6$, and TNF- $\alpha$ ), as well as iNOS, nNOS, and COX-2 expression via the modulation of NF-KB activation [24].

In addition, Zhang et al. [139] found that astaxanthin administration could alleviate early brain injury via suppressing the inflammation damage induced by subarachnoid hemorrhage. In particular, $75 \mathrm{mg} / \mathrm{kg}$ astaxanthin significantly reduced the elevated cortical levels of inflammatory mediators, together with the degree of neutrophil infiltration.

A food supplement approved by the U.S. Food and Drug Administration (FDA), named Aquamin, is a natural multi-mineral derived from the marine red seaweed Lithothamnion corallioides. Aquamin was evaluated for its anti-neuroinflammatory potential, and in cortical glial-enriched cells was able to suppress the release of LPS-induced TNF- $\alpha$ and IL-1 $\beta$. Recently, several authors suggested that anti-inflammatory and antioxidative agents could prevent the deposition of $A \beta$ and the subsequent brain damage $[140,141]$. Indeed, in the promoter of neuronal beta-secretase 1 (BACE1), the enzyme involved in A $\beta$ buildup, NF-KB DNA consensus sequences are present [142]. So, it could be beneficial in treating $\mathrm{AD}$ to reduce microglia-mediated neuroinflammation and increase microglia scavenger activity for toxic A $\beta$ aggregates [143]. The ethanol extract of Nannochloropsis oceanica demonstrated anti-inflammatory, antioxidative, and anti-amyloidogenesis activities in a mouse model of LPS-induced AD [141]. The authors recently found that the main component of Nannochloropsis oceanica is eicosapentaenoic acid (EPA), suggesting that it could be responsible for the neuroprotective effects. The depolymerization of the polysaccharide alginate, found in many marine brown algae, produces alginate-derived oligosaccharide with various biological activities depending on the degradation method used [79]. The alginate-derived oligosaccharide produced by enzymatic depolymerization showed anti-inflammatory activity by repressing the LPS and A $\beta$-induced production of inflammatory cytokines and mediators in microglial cells. These effects have been associated with the inactivation of the TLR4/NF- $\mathrm{KB}$ axis [79]. Interestingly, the interaction between this oligosaccharide and TLR4 promotes the uptake of toxic $A \beta$ aggregates. Regarding the possibility of alginate-derived oligosaccharide crossing the BBB, the authors declared an average molecular weight of $1500 \mathrm{Da}$ and previous works demonstrated that oligosaccharides produced by enzymatic depolymerization are able to pass through the BBB easily [25,144]. Differently, Bi et al. [13] synthesized a seleno-polysaccharide from alginate-derived polymannuronate. Using in vitro/in vivo models of microglia and astrocyte activation, the pre-treatment with seleno-polymannuronate reduced the overgeneration of proinflammatory mediators, including NO, PGE 2 , TNF- $\alpha$, IL-6, and IL-1 $\beta$ as well as iNOS and COX-2, by suppressing the MAPK/NF-KB signaling pathway. Cui et al. [145] assessed whether fucoidan, a class of fucose-enriched sulfated polysaccharides isolated from Laminaria japonica, protects dopaminergic neurons from inflammation-mediated damage in a PD inflammatory rat model induced by an intranigral injection of LPS. Fucoidan was able to improve behavioral deficits in mice by protecting them from the loss of dopaminergic neurons. Other important anti-AD and anti-inflammatory effects have been manifested by the glycoproteins purified from brown alga Undaria pinnatifida [146]. Undaria pinnatifida displayed dose-responsive inhibition for AChE and BChE with an $\mathrm{IC}_{50}$ of 63.56 and $99.03 \mu \mathrm{g} / \mathrm{mL}$, respectively, and has been shown to inhibit BACE1, acting on the neurotransmitter acetylcholine and on the formation and accumulation of $A \beta$ aggregates. Moreover, Undaria pinnatifida promotes cell survival and neurite extension, preventing inflammation status.

Epidemiological studies demonstrate a negative correlation between the use of non-steroidal anti-inflammatory drugs (NSAIDs) and the incidence of inflammation in the nervous system, which in turn participates in the development of neurodegenerative diseases [120]. The NSAIDs' mechanism of action involves the inhibition of the inflammatory mediator release. Marine algae can control the 
inflammatory process in microglia, suggesting their potential role as neuroprotective agents. Moreover, the signaling pathways involved in the neuroprotective activity of algae are multiple. The complexity of neurodegenerative diseases makes them difficult to counteract with single-target molecules. In this context, marine algae, with their pleiotropic effects, have a great potential for application as anti-neuroinflammatory agents. However, further studies are needed, along with clinical trials to confirm marine algae's anti-neuroinflammatory activity.

\section{Conclusions}

The wide range of biological and bioactive molecules found in marine algae represents a challenge for researchers involved in the study of neuroinflammation/neurodegeneration processes. Marine algae extracts and many marine algae constituents belonging to different chemical classes have been demonstrated to exert preventive/protective effects against neuro-inflammation (Table 2). In particular, they have been demonstrated to be effective in reducing inflammatory mediators like NO, TNF- $\alpha$, IL-6, and IL-1 $\beta$, in downregulating inflammatory enzymes like iNOS and COX-2, and in modulating the signaling pathways that lead to NF- $\mathrm{KB}$ activation. Moreover, most of the compounds isolated from marine algae have also shown antioxidant activity. Oxidative stress represents a hallmark of neuroinflammation and its counteraction could be a successful strategy in the prevention of neurodegeneration. ROS production is strictly related to neuro-inflammation, and marine algae compounds with both antioxidant and anti-inflammatory activities are good candidates to counteract neurodegeneration thanks to their pleiotropic activity. A better knowledge of these molecules should be associated with an implementation in the extraction and purification procedures in order to obtain marine algae extracts with standardized concentrations to be applied in in vitro studies. In fact, the choice of an appropriate extraction method can deeply influence the presence and concentration of the bioactive compounds. Moreover, the ability of marine algae constituents to cross the blood-brain barrier has not been investigated, which calls into question the possibility of developing them as neuroprotective agents. Also, studies on potential adverse effects are lacking. Although still in their infancy, studies on the anti-neuroinflammatory effects of marine algae compounds should be corroborated by clinical trials. Currently there is a paucity of information reported in the literature, which only contains studies on in vitro or animal models. Human studies could strengthen the choice of marine algae products as potential nutraceutical compounds for the prevention of neuro-inflammation.

Table 2. Studies showing anti-neuroinflammatory activities of marine algae.

\begin{tabular}{|c|c|c|c|}
\hline $\begin{array}{l}\text { Marine Algae } \\
\text { Extract/Bioactive } \\
\text { Compound }\end{array}$ & Treatment Conc. & Experimental Model & Key Findings \\
\hline $\begin{array}{l}\text { Ulva conglobata } \\
\text { methanol extract }\end{array}$ & $10-50 \mu \mathrm{g} / \mathrm{mL}$ & $\begin{array}{l}\text { mouse hippocampal } \\
\text { HT-22 cells; mouse } \\
\text { microglial BV-2 cells }\end{array}$ & $\begin{array}{l}\text { Restoration of cellular viability in } \\
\text { HT-22 cells; downregulation of } \\
\text { COX-2 and iNOS in BV-2 cells [22] }\end{array}$ \\
\hline $\begin{array}{l}\text { Exane fraction of } \\
\text { Myagropsis myagroides } \\
\text { ethanolic extract }\end{array}$ & $5-25 \mu \mathrm{g} / \mathrm{mL}$ & $\begin{array}{l}\text { mouse microglial } \\
\text { BV-2 cells }\end{array}$ & $\begin{array}{l}\text { Decreased release of inflammatory } \\
\text { cytokines, inactivation of NF- } \mathrm{B} \\
\text { and reduced mRNA and protein } \\
\text { levels of iNOS and COX-2 [124] }\end{array}$ \\
\hline $\begin{array}{l}\text { Myagropsis myagroides } \\
\text { ethanolic extract }\end{array}$ & $5-25 \mu \mathrm{g} / \mathrm{mL}$ & $\begin{array}{l}\text { mouse microglial } \\
\text { BV-2 cells }\end{array}$ & $\begin{array}{c}\text { Reduction in NO, } \text { PGE }_{2}, \mathrm{IL}-6, \\
\text { IL-1 } \beta \text { and TNF- } \alpha \text { release; } \\
\text { inhibition of ERKs-JNKs/NF-kB } \\
\text { axis [125] }\end{array}$ \\
\hline $\begin{array}{c}\text { Padina australis, } \\
\text { Sargassum polycystum } \\
\text { and Caulerpa racemosa } \\
\text { extracts }\end{array}$ & $0.05-0.4 \mathrm{mg} / \mathrm{mL}$ & $\begin{array}{l}\text { mouse microglial } \\
\text { C8-B4 cells }\end{array}$ & $\begin{array}{c}\text { Decreased release of } \\
\text { pro-inflammatory mediators (NO, } \\
\left.\text { PGE }_{2}, \text { IL-6, IL-1 } \beta \text { and TNF- } \alpha\right) \\
{[126]}\end{array}$ \\
\hline
\end{tabular}


Table 2. Cont.

\begin{tabular}{|c|c|c|c|}
\hline $\begin{array}{l}\text { Marine Algae } \\
\text { Extract/Bioactive } \\
\text { Compound }\end{array}$ & Treatment Conc. & Experimental Model & Key Findings \\
\hline $\begin{array}{l}\text { Fucosterol from } \\
\text { Padina australis }\end{array}$ & $0.004-192 \mu \mathrm{M}$ & $\begin{array}{l}\text { mouse microglial } \\
\text { C8-B4 and BV-2 cells }\end{array}$ & $\begin{array}{l}\text { Inhibition of AChE and } \mathrm{BChE} \text {; } \\
\text { reduction in release of NO, PGE } \\
\text { IL-6, IL- } 1 \beta \text { and TNF- } \alpha \text { in } \\
\text { LPS-stimulated C8-B4 cells; } \\
\text { prevented production of NO, IL-6 } \\
\text { and TNF- } \alpha \text { in } A \beta_{42} \text {-stimulated } \\
\text { BV-2 cells [128] }\end{array}$ \\
\hline $\begin{array}{l}\text { Eckol, dieckol and } \\
\text { 8,8'-bieckol from } \\
\text { Ecklonia cava }\end{array}$ & $1-50 \mu \mathrm{M}$ & $\begin{array}{l}\text { rat neuronal PC12 } \\
\text { cells }\end{array}$ & $\begin{array}{c}\text { Antioxidant activity; } \\
\text { anti-apoptotic effects; decrease in } \\
\text { key inflammatory proteins } \\
(\mathrm{COX}-2, \text { iNOS, IL-1 } \beta \text { and TNF- } \alpha) \\
{[130]}\end{array}$ \\
\hline $\begin{array}{l}\text { Dieckol from Ecklonia } \\
\text { cava }\end{array}$ & $50-300 \mu \mathrm{g} / \mathrm{mL}$ & $\begin{array}{l}\text { mouse microglial } \\
\text { BV-2 cells }\end{array}$ & $\begin{array}{l}\text { Inhibition of LPS-induced iNOS } \\
\text { and COX-2 protein and mRNA } \\
\text { expression; suppression of p-38/ } \\
\text { NF-kB pathway; ROS scavenging } \\
\text { activity [129] }\end{array}$ \\
\hline $\begin{array}{l}\text { Phlorofucofuroeckol } \\
\text { B from Ecklonia } \\
\text { stolonifera }\end{array}$ & $10-40 \mu \mathrm{M}$ & $\begin{array}{l}\text { mouse microglial } \\
\text { BV-2 cells }\end{array}$ & $\begin{array}{l}\text { Inhibition of IкB- } \alpha / \text { NF- } \kappa B \text { and } \\
\text { Akt/ERK/JNK pathways [23] }\end{array}$ \\
\hline $\begin{array}{l}\text { Floridoside from } \\
\text { Laurencia undulata }\end{array}$ & $1-50 \mu \mathrm{M}$ & $\begin{array}{l}\text { mouse microglial } \\
\text { BV-2 cells }\end{array}$ & $\begin{array}{l}\text { Inhibition of LPS-induced NO and } \\
\text { ROS production; downregulation } \\
\text { of COX-2 and iNOS mRNA and } \\
\text { protein levels by reducing p38 and } \\
\text { ERK phosphorylation [131] }\end{array}$ \\
\hline Fucoxanthin & $5-50 \mu \mathrm{M}$ & $\begin{array}{l}\text { mouse microglial } \\
\text { BV-2 cells }\end{array}$ & $\begin{array}{c}\text { Attenuation of } \mathrm{A} \beta_{42} \text {-induced } \\
\text { cytokines release (NO, PGE } 2 \text {, IL-6, } \\
\text { IL- } 1 \beta \text { and TNF- } \alpha \text { ) and enzymes } \\
\text { upregulation (COX-2, iNOS) by } \\
\text { suppressing MAPKs } \\
\text { phosphorylation; protection from } \\
\mathrm{H}_{2} \mathrm{O}_{2} \text {-induced ROS release and } \\
\text { DNA damage by recovering } \\
\text { antioxidant enzymes [114] }\end{array}$ \\
\hline Astaxanthin & $20-80 \mathrm{mg} / \mathrm{Kg}$ & male ICR mice & $\begin{array}{l}\text { Reversed LPS-induced } \\
\text { depressive-like behaviors; } \\
\text { attenuation of cytokines level } \\
\text { (IL-6, IL-1 } \beta \text { and TNF- } \alpha \text { ) and } \\
\text { antagonization of iNOS, nNOS } \\
\text { and COX-2 expression in the } \\
\text { hippocampus and prefrontal } \\
\text { cortex [24] }\end{array}$ \\
\hline Astaxanthin & $75 \mathrm{mg} / \mathrm{Kg}$ & $\begin{array}{c}\text { male } \\
\text { Sprague-Dawley rats }\end{array}$ & $\begin{array}{l}\text { Amelioration in cerebral edema, } \\
\text { blood-brain barrier disruption, } \\
\text { neurological dysfunction and } \\
\text { neuronal degeneration after the } \\
\text { induction of subarachnoid } \\
\text { hemorrhage; downregulation of } \\
\text { NF- } k \text { B activity, and intercellular } \\
\text { adhesion molecule-1, IL-1 } \beta \text { and } \\
\text { TNF- } \alpha \text { expression [139] }\end{array}$ \\
\hline
\end{tabular}


Table 2. Cont.

\begin{tabular}{|c|c|c|c|}
\hline $\begin{array}{l}\text { Marine Algae } \\
\text { Extract/Bioactive } \\
\text { Compound }\end{array}$ & Treatment Conc. & Experimental Model & Key Findings \\
\hline Aquamin $^{\mathrm{TM}}$ & $0.05-2 \mathrm{mg} / \mathrm{mL}$ & $\begin{array}{l}\text { cortical glial-enriched } \\
\text { cultures from } \\
\text { Sprague-Dawley rat } \\
\text { pups }\end{array}$ & $\begin{array}{l}\text { Attenuation of LPS-induced IL-1 } \beta \\
\text { and TNF- } \alpha \text { secretion [147] }\end{array}$ \\
\hline $\begin{array}{l}\text { Nannochloropsis } \\
\text { oceanica ethanol } \\
\text { extract }\end{array}$ & 50-100 mg/Kg & male ICR mice & $\begin{array}{c}\text { Decrease of ROS and } \\
\text { malondialdehyde levels; } \\
\text { improvement of LPS-induced } \\
\text { memory impairment; suppression } \\
\text { of } A \beta_{42} \text { generation by } \\
\text { downregulating APP and BACE1 } \\
\text { expression [141] }\end{array}$ \\
\hline $\begin{array}{l}\text { Alginate-derived } \\
\text { oligosaccharide }\end{array}$ & $50-500 \mu \mathrm{g} / \mathrm{mL}$ & $\begin{array}{l}\text { mouse microglial } \\
\text { BV-2 cells }\end{array}$ & $\begin{array}{c}\text { Inhibition of LPS/ } \mathrm{A} \beta_{42} \text {-induced } \\
\mathrm{NO} \text { and } \mathrm{PGE} 2 \text { production, COX-2 } \\
\text { and iNOS expression, and } \\
\text { cytokines secretion; attenuation of } \\
\text { TLR4 and NF- } \mathrm{B} \text { B overexpression; } \\
\text { promotion of } \mathrm{A} \beta \text { phagocytosis } \\
{[79]}\end{array}$ \\
\hline Seleno-polymannuronate & $\begin{array}{l}0.5 \mathrm{mg} / \mathrm{mL} \\
0.8 \mathrm{mg} / \mathrm{mL}\end{array}$ & $\begin{array}{l}\text { primary microglia } \\
\text { and astrocytes from } \\
\text { BALB/c mouse pups; } \\
\text { female BALB/c mice }\end{array}$ & $\begin{array}{l}\text { In LPS-activated primary cells, } \\
\text { attenuation of NF- } \mathrm{kB} \text { and MAPK } \\
\text { signaling with the reduction of } \\
\text { NO, PGE } 2 \text { production, } \\
\text { downregulation of COX-2 and } \\
\text { iNOS expression, and IL- } 6 \text {, IL-1 } \beta \\
\text { and TNF- } \alpha \text { secretion; decrease of } \\
\text { Iba1- and GFAP-positive cells in } \\
\text { the brain of a mouse model of } \\
\text { LPS-induced inflammation [13] }\end{array}$ \\
\hline Fucoidan & $\begin{array}{l}7.5 \mathrm{mg} / \mathrm{Kg}, 15 \mathrm{mg} / \mathrm{Kg} ; \\
\quad 31.25-125 \mu \mathrm{g} / \mathrm{mL}\end{array}$ & $\begin{array}{l}\text { male } \\
\text { Sprague-Dawley rats; } \\
\text { primary microglia } \\
\text { from neonatal } \\
\text { Sprague-Dawley rats }\end{array}$ & $\begin{array}{l}\text { Improvement of behavioral } \\
\text { deficits and prevention of } \\
\text { dopaminergic neuron loss; } \\
\text { inhibition of ROS and TNF- } \alpha \\
\text { release [145] }\end{array}$ \\
\hline $\begin{array}{l}\text { Glycoprotein from } \\
\text { Undaria pinnatifida }\end{array}$ & $5-45 \mu \mathrm{g} / \mathrm{mL}$ & $\begin{array}{c}\text { primary } \\
\text { hippocampal cells } \\
\text { from embryonal } \\
\text { Sprague-Dawley rats }\end{array}$ & $\begin{array}{l}\text { Inhibition of } \mathrm{AChE}, \mathrm{BChE} \text { and } \\
\text { BACE1; promotion of cell survival } \\
\text { and neurite extension [146] }\end{array}$ \\
\hline
\end{tabular}

Funding: This work was supported by MIUR-PRIN 2015 (N. 20152HKF3Z).

Conflicts of Interest: The authors declare no conflict of interest. 


\section{Abbreviations}

$\begin{array}{ll}\text { AChE } & \text { Acetylcholinesterase } \\ \text { AD } & \text { Alzheimer's disease } \\ \text { ALS } & \text { Amyotrophic lateral sclerosis } \\ \text { AP-1 } & \text { Activating protein 1 } \\ \text { A- } & \text { Amyloid beta } \\ \text { BACE1 } & \text { Beta-secretase 1 } \\ \text { BBB } & \text { Blood-brain barrier } \\ \text { BChE } & \text { Butyrylcholinesterase } \\ \text { CNS } & \text { Central nervous system } \\ \text { COX-2 } & \text { Cyclooxygenase-2 } \\ \text { EPA } & \text { Eicosapentaenoic acid } \\ \text { HD } & \text { Huntington's disease } \\ \text { IL } & \text { Interleukin } \\ \text { iNOS } & \text { Inducible nitric oxide synthase } \\ \text { JNK } & \text { c-Jun N-terminal kinases } \\ \text { LPS } & \text { Lipopolysaccharide } \\ \text { MAPKs } & \text { Mitogen-activated protein kinases cascade } \\ \text { MS } & \text { Multiple sclerosis } \\ \text { NF- }- \text { B } & \text { Nuclear factor kB } \\ \text { NGF } & \text { Nerve growth factor } \\ \text { nNOS } & \text { Neuronal nitric oxide synthase } \\ \text { NO } & \text { Nitric oxide } \\ \text { NSAIDs } & \text { Non-steroidal anti-inflammatory drugs } \\ \text { PD } & \text { Parkinson's disease } \\ \text { PGE } 2 & \text { Prostaglandin E2 } \\ \text { PUFA } & \text { Polyunsaturated fatty acids } \\ \text { TBI } & \text { Traumatic brain injury } \\ \text { TGF } \beta & \text { Transforming growth factor beta } \\ \text { TLRs } & \text { Toll-like receptor } \\ \text { TNF- } \alpha & \text { Tumor necrosis factor alpha } \\ & \end{array}$

\section{References}

1. Höglund, K.; Salter, H. Molecular biomarkers of neurodegeneration. Expert Rev. Mol. Diagn. 2013, 13, 845-861. [CrossRef] [PubMed]

2. Angeloni, C.; Prata, C.; Dalla Sega, F.V.; Piperno, R.; Hrelia, S. Traumatic brain injury and NADPH oxidase: A deep relationship. Oxid. Med. Cell Longev. 2015, 2015, 370312. [CrossRef] [PubMed]

3. Tarozzi, A.; Angeloni, C.; Malaguti, M.; Morroni, F.; Hrelia, S.; Hrelia, P. Sulforaphane as a potential protective phytochemical against neurodegenerative diseases. Oxid. Med. Cell Longev. 2013, 2013, 415078. [CrossRef] [PubMed]

4. Hammond, T.R.; Marsh, S.E.; Stevens, B. Immune Signaling in Neurodegeneration. Immunity 2019, 50, 955-974. [CrossRef] [PubMed]

5. Frank-Cannon, T.C.; Alto, L.T.; McAlpine, F.E.; Tansey, M.G. Does neuroinflammation fan the flame in neurodegenerative diseases? Mol. Neurodegener 2009, 4, 47. [CrossRef] [PubMed]

6. Morales, I.; Guzmán-Martínez, L.; Cerda-Troncoso, C.; Farías, G.A.; Maccioni, R.B. Neuroinflammation in the pathogenesis of Alzheimer's disease. A rational framework for the search of novel therapeutic approaches. Front. Cell Neurosci. 2014, 8, 112. [CrossRef] [PubMed]

7. Glass, C.K.; Saijo, K.; Winner, B.; Marchetto, M.C.; Gage, F.H. Mechanisms underlying inflammation in neurodegeneration. Cell 2010, 140, 918-934. [CrossRef]

8. Spencer, J.P.; Vafeiadou, K.; Williams, R.J.; Vauzour, D. Neuroinflammation: modulation by flavonoids and mechanisms of action. Mol. Asp. Med. 2012, 33, 83-97. [CrossRef]

9. Schain, M.; Kreisl, W.C. Neuroinflammation in Neurodegenerative Disorders-a Review. Curr. Neurol. Neurosci. Rep. 2017, 17, 25. [CrossRef] 
10. Sofroniew, M.V. Multiple roles for astrocytes as effectors of cytokines and inflammatory mediators. Neuroscientist 2014, 20, 160-172. [CrossRef]

11. Neal, M.; Richardson, J.R. Epigenetic regulation of astrocyte function in neuroinflammation and neurodegeneration. Biochim Biophys Acta. Mol. Basis Dis. 2018, 1864, 432-443. [CrossRef] [PubMed]

12. Motori, E.; Puyal, J.; Toni, N.; Ghanem, A.; Angeloni, C.; Malaguti, M.; Cantelli-Forti, G.; Berninger, B.; Conzelmann, K.K.; Götz, M.; et al. Inflammation-induced alteration of astrocyte mitochondrial dynamics requires autophagy for mitochondrial network maintenance. Cell Metab 2013, 18, 844-859. [CrossRef] [PubMed]

13. Decheng, B.; Qiuxian, L.; Qingguo, H.; Nan, C.; Hanxing, H.; Weishan, F.; Jiang, Y.; Xiaofan, L.; Hong, X.; Xiuting, L.; et al. Seleno-polymannuronate attenuates neuroinflammation by suppressing microglial and astrocytic activation. J. Funct. Foods 2018, 51, 113-120.

14. Ning, C.; Wang, H.D.; Gao, R.; Chang, Y.C.; Hu, F.; Meng, X.; Huang, S.Y. Marine-derived protein kinase inhibitors for neuroinflammatory diseases. Biomed. Eng. Online 2018, 17, 46. [CrossRef] [PubMed]

15. Park, E.J.; Pezzuto, J.M. Antioxidant marine products in cancer chemoprevention. Antioxid Redox Signal. 2013, 19, 115-138. [CrossRef] [PubMed]

16. Pejin, B.; Jovanovic, K.K.; Savic, A.G. New antitumour natural products from marine red algae: Covering the period from 2003 to 2012. Mini. Rev. Med. Chem. 2015, 15, 720-730. [CrossRef] [PubMed]

17. Jin, Q.; Yu, H.; Li, P. The Evaluation and Utilization of Marine-derived Bioactive Compounds with Anti-obesity Effect. Curr. Med. Chem. 2018, 25, 861-878. [CrossRef] [PubMed]

18. Huang, C.; Zhang, Z.; Cui, W. Marine-Derived Natural Compounds for the Treatment of Parkinson's Disease. Mar. Drugs 2019, 17, 221. [CrossRef]

19. Newman, D.J.; Cragg, G.M. Advanced preclinical and clinical trials of natural products and related compounds from marine sources. Curr. Med. Chem. 2004, 11, 1693-1713. [CrossRef] [PubMed]

20. Brown, E.S.; Allsopp, P.J.; Magee, P.J.; Gill, C.I.; Nitecki, S.; Strain, C.R.; McSorley, E.M. Seaweed and human health. Nutr. Rev. 2014, 72, 205-216. [CrossRef] [PubMed]

21. Fernando, I.P.S.; Nah, J.W.; Jeon, Y.J. Potential anti-inflammatory natural products from marine algae. Env. Toxicol Pharm. 2016, 48, 22-30. [CrossRef] [PubMed]

22. Jin, D.Q.; Lim, C.S.; Sung, J.Y.; Choi, H.G.; Ha, I.; Han, J.S. Ulva conglobata, a marine algae, has neuroprotective and anti-inflammatory effects in murine hippocampal and microglial cells. Neurosci. Lett. 2006, 402, 154-158. [CrossRef] [PubMed]

23. Yu, D.K.; Lee, B.; Kwon, M.; Yoon, N.; Shin, T.; Kim, N.G.; Choi, J.S.; Kim, H.R. Phlorofucofuroeckol B suppresses inflammatory responses by down-regulating nuclear factor $\kappa B$ activation via Akt, ERK, and JNK in LPS-stimulated microglial cells. Int. Immunopharmacol 2015, 28, 1068-1075. [CrossRef]

24. Jiang, X.; Chen, L.; Shen, L.; Chen, Z.; Xu, L.; Zhang, J.; Yu, X. Trans-astaxanthin attenuates lipopolysaccharide-induced neuroinflammation and depressive-like behavior in mice. Brain Res. 2016, 1649, 30-37. [CrossRef] [PubMed]

25. Fan, Y.; Hu, J.; Li, J.; Yang, Z.; Xin, X.; Wang, J.; Ding, J.; Geng, M. Effect of acidic oligosaccharide sugar chain on scopolamine-induced memory impairment in rats and its related mechanisms. Neurosci. Lett. 2005, 374, 222-226. [CrossRef]

26. Scarpignato, C.; Dolak, W.; Lanas, A.; Matzneller, P.; Renzulli, C.; Grimaldi, M.; Zeitlinger, M.; Bjarnason, I. Rifaximin Reduces the Number and Severity of Intestinal Lesions Associated With Use of Nonsteroidal Anti-Inflammatory Drugs in Humans. Gastroenterology 2017, 152, 980-982.e983. [CrossRef]

27. Yuan, G.; Wahlqvist, M.L.; He, G.; Yang, M.; Li, D. Natural products and anti-inflammatory activity. Asia Pac. J. Clin. Nutr. 2006, 15, 143-152.

28. Adams, K.L.; Gallo, V. The diversity and disparity of the glial scar. Nat. Neurosci. 2018, 21, 9-15. [CrossRef]

29. Nayak, D.; Roth, T.L.; McGavern, D.B. Microglia development and function. Annu. Rev. Immunol. 2014, 32, 367-402. [CrossRef]

30. Ginhoux, F.; Greter, M.; Leboeuf, M.; Nandi, S.; See, P.; Gokhan, S.; Mehler, M.F.; Conway, S.J.; Ng, L.G.; Stanley, E.R.; et al. Fate mapping analysis reveals that adult microglia derive from primitive macrophages. Science 2010, 330, 841-845. [CrossRef]

31. Subhramanyam, C.S.; Wang, C.; Hu, Q.; Dheen, S.T. Microglia-mediated neuroinflammation in neurodegenerative diseases. Semin Cell Dev. Biol. 2019. [CrossRef] [PubMed] 
32. Schwartz, M.; Kipnis, J.; Rivest, S.; Prat, A. How do immune cells support and shape the brain in health, disease, and aging? J. Neurosci. 2013, 33, 17587-17596. [CrossRef] [PubMed]

33. Ueno, M.; Fujita, Y.; Tanaka, T.; Nakamura, Y.; Kikuta, J.; Ishii, M.; Yamashita, T. Layer V cortical neurons require microglial support for survival during postnatal development. Nat. Neurosci. 2013, 16, 543-551. [CrossRef] [PubMed]

34. Takahashi, K.; Rochford, C.D.; Neumann, H. Clearance of apoptotic neurons without inflammation by microglial triggering receptor expressed on myeloid cells-2. J. Exp. Med. 2005, 201, 647-657. [CrossRef] [PubMed]

35. Liao, H.; Bu, W.Y.; Wang, T.H.; Ahmed, S.; Xiao, Z.C. Tenascin-R plays a role in neuroprotection via its distinct domains that coordinate to modulate the microglia function. J. Biol. Chem. 2005, 280, 8316-8323. [CrossRef] [PubMed]

36. Drögemüller, K.; Helmuth, U.; Brunn, A.; Sakowicz-Burkiewicz, M.; Gutmann, D.H.; Mueller, W.; Deckert, M.; Schlüter, D. Astrocyte gp130 expression is critical for the control of Toxoplasma encephalitis. J. Immunol. 2008, 181, 2683-2693. [CrossRef] [PubMed]

37. Cho, M.L.; Min, S.Y.; Chang, S.H.; Kim, K.W.; Heo, S.B.; Lee, S.H.; Park, S.H.; Cho, C.S.; Kim, H.Y. Transforming growth factor beta 1(TGF-beta1) down-regulates TNFalpha-induced RANTES production in rheumatoid synovial fibroblasts through NF-kappaB-mediated transcriptional repression. Immunol. Lett. 2006, 105, 159-166. [CrossRef]

38. Wyss-Coray, T.; Mucke, L. Inflammation in neurodegenerative disease-A double-edged sword. Neuron 2002, 35, 419-432. [CrossRef]

39. Hoshino, K.; Takeuchi, O.; Kawai, T.; Sanjo, H.; Ogawa, T.; Takeda, Y.; Takeda, K.; Akira, S. Cutting edge: Toll-like receptor 4 (TLR4)-deficient mice are hyporesponsive to lipopolysaccharide: evidence for TLR4 as the Lps gene product. J. Immunol. 1999, 162, 3749-3752.

40. Tang, Y.; Le, W. Differential Roles of M1 and M2 Microglia in Neurodegenerative Diseases. Mol. Neurobiol. 2016, 53, 1181-1194. [CrossRef]

41. Colton, C.A.; Gilbert, D.L. Production of superoxide anions by a CNS macrophage, the microglia. FEBS Lett. 1987, 223, 284-288. [CrossRef]

42. Graeber, M.B.; Streit, W.J.; Kreutzberg, G.W. Axotomy of the rat facial nerve leads to increased CR3 complement receptor expression by activated microglial cells. J. Neurosci. Res. 1988, 21, 18-24. [CrossRef] [PubMed]

43. Chen, W.W.; Zhang, X.; Huang, W.J. Role of neuroinflammation in neurodegenerative diseases. Mol. Med. Rep. 2016, 13, 3391-3396. [CrossRef] [PubMed]

44. Lull, M.E.; Block, M.L. Microglial activation and chronic neurodegeneration. Neurotherapeutics 2010, 7, 354-365. [CrossRef] [PubMed]

45. Licastro, F.; Hrelia, S.; Porcellini, E.; Malaguti, M.; Di Stefano, C.; Angeloni, C.; Carbone, I.; Simoncini, L.; Piperno, R. Peripheral Inflammatory Markers and Antioxidant Response during the Post-Acute and Chronic Phase after Severe Traumatic Brain Injury. Front. Neurol. 2016, 7, 189. [CrossRef] [PubMed]

46. Tansey, M.G.; McCoy, M.K.; Frank-Cannon, T.C. Neuroinflammatory mechanisms in Parkinson's disease: potential environmental triggers, pathways, and targets for early therapeutic intervention. Exp. Neurol. 2007, 208, 1-25. [CrossRef] [PubMed]

47. Das Sarma, J. Microglia-mediated neuroinflammation is an amplifier of virus-induced neuropathology. $J$. Neurovirol. 2014, 20, 122-136. [CrossRef]

48. Chen, H.; Chan, D.C. Mitochondrial dynamics-fusion, fission, movement, and mitophagy-in neurodegenerative diseases. Hum. Mol. Genet. 2009, 18, R169-R176. [CrossRef]

49. Xiang, W.; Chao, Z.Y.; Feng, D.Y. Role of Toll-like receptor/MYD88 signaling in neurodegenerative diseases. Rev. Neurosci. 2015, 26, 407-414. [CrossRef]

50. Lehnardt, S.; Massillon, L.; Follett, P.; Jensen, F.E.; Ratan, R.; Rosenberg, P.A.; Volpe, J.J.; Vartanian, T. Activation of innate immunity in the CNS triggers neurodegeneration through a Toll-like receptor 4-dependent pathway. Proc. Natl. Acad. Sci USA 2003, 100, 8514-8519. [CrossRef]

51. Balducci, C.; Frasca, A.; Zotti, M.; La Vitola, P.; Mhillaj, E.; Grigoli, E.; Iacobellis, M.; Grandi, F.; Messa, M.; Colombo, L.; et al. Toll-like receptor 4-dependent glial cell activation mediates the impairment in memory establishment induced by $\beta$-amyloid oligomers in an acute mouse model of Alzheimer's disease. Brain Behav. Immun. 2017, 60, 188-197. [CrossRef] [PubMed] 
52. Capiralla, H.; Vingtdeux, V.; Zhao, H.; Sankowski, R.; Al-Abed, Y.; Davies, P.; Marambaud, P. Resveratrol mitigates lipopolysaccharide- and A $\beta$-mediated microglial inflammation by inhibiting the TLR4/NF- $\mathrm{kB} / \mathrm{STAT}$ signaling cascade. J. Neurochem. 2012, 120, 461-472. [CrossRef] [PubMed]

53. Lv, R.; Du, L.; Liu, X.; Zhou, F.; Zhang, Z.; Zhang, L. Rosmarinic acid attenuates inflammatory responses through inhibiting HMGB1/TLR4/NF-kB signaling pathway in a mouse model of Parkinson's disease. Life Sci. 2019, 223, 158-165. [CrossRef] [PubMed]

54. Caso, J.R.; Pradillo, J.M.; Hurtado, O.; Lorenzo, P.; Moro, M.A.; Lizasoain, I. Toll-like receptor 4 is involved in brain damage and inflammation after experimental stroke. Circulation 2007, 115, 1599-1608. [CrossRef] [PubMed]

55. Lu, Y.C.; Yeh, W.C.; Ohashi, P.S. LPS/TLR4 signal transduction pathway. Cytokine 2008, 42, 145-151. [CrossRef] [PubMed]

56. Hanada, T.; Yoshimura, A. Regulation of cytokine signaling and inflammation. Cytokine Growth Factor Rev. 2002, 13, 413-421. [CrossRef]

57. Shabab, T.; Khanabdali, R.; Moghadamtousi, S.Z.; Kadir, H.A.; Mohan, G. Neuroinflammation pathways: a general review. Int J. Neurosci 2017, 127, 624-633. [CrossRef]

58. Kawai, T.; Akira, S. Signaling to NF-kappaB by Toll-like receptors. Trends Mol. Med. 2007, 13, 460-469. [CrossRef]

59. Qian, Y.; Liu, C.; Hartupee, J.; Altuntas, C.Z.; Gulen, M.F.; Jane-Wit, D.; Xiao, J.; Lu, Y.; Giltiay, N.; Liu, J.; et al. The adaptor Act1 is required for interleukin 17-dependent signaling associated with autoimmune and inflammatory disease. Nat. Immunol 2007, 8, 247-256. [CrossRef]

60. Colombo, E.; Di Dario, M.; Capitolo, E.; Chaabane, L.; Newcombe, J.; Martino, G.; Farina, C. Fingolimod may support neuroprotection via blockade of astrocyte nitric oxide. Ann. Neurol. 2014, 76, 325-337. [CrossRef]

61. Mayo, L.; Trauger, S.A.; Blain, M.; Nadeau, M.; Patel, B.; Alvarez, J.I.; Mascanfroni, I.D.; Yeste, A.; Kivisäkk, P.; Kallas, K.; et al. Regulation of astrocyte activation by glycolipids drives chronic CNS inflammation. Nat. Med. 2014, 20, 1147-1156. [CrossRef] [PubMed]

62. Füchtbauer, L.; Groth-Rasmussen, M.; Holm, T.H.; Løbner, M.; Toft-Hansen, H.; Khorooshi, R.; Owens, T. Angiotensin II Type 1 receptor (AT1) signaling in astrocytes regulates synaptic degeneration-induced leukocyte entry to the central nervous system. Brain Behav. Immun. 2011, 25, 897-904. [CrossRef] [PubMed]

63. Brambilla, R.; Bracchi-Ricard, V.; Hu, W.H.; Frydel, B.; Bramwell, A.; Karmally, S.; Green, E.J.; Bethea, J.R. Inhibition of astroglial nuclear factor kappaB reduces inflammation and improves functional recovery after spinal cord injury. J. Exp. Med. 2005, 202, 145-156. [CrossRef] [PubMed]

64. Fu, E.S.; Zhang, Y.P.; Sagen, J.; Candiotti, K.A.; Morton, P.D.; Liebl, D.J.; Bethea, J.R.; Brambilla, R. Transgenic inhibition of glial NF-kappa B reduces pain behavior and inflammation after peripheral nerve injury. Pain 2010, 148, 509-518. [CrossRef] [PubMed]

65. Youssef, M.; Ibrahim, A.; Akashi, K.; Hossain, M.S. PUFA-Plasmalogens Attenuate the LPS-Induced Nitric Oxide Production by Inhibiting the NF-kB, p38 MAPK and JNK Pathways in Microglial Cells. Neuroscience 2019, 397, 18-30. [CrossRef] [PubMed]

66. Yan, Z.; Gibson, S.A.; Buckley, J.A.; Qin, H.; Benveniste, E.N. Role of the JAK/STAT signaling pathway in regulation of innate immunity in neuroinflammatory diseases. Clin. Immunol. 2018, 189, 4-13. [CrossRef] [PubMed]

67. Yeung, Y.T.; Aziz, F.; Guerrero-Castilla, A.; Arguelles, S. Signaling Pathways in Inflammation and Anti-inflammatory Therapies. Curr. Pharm Des. 2018, 24, 1449-1484. [CrossRef]

68. Meares, G.P.; Liu, Y.; Rajbhandari, R.; Qin, H.; Nozell, S.E.; Mobley, J.A.; Corbett, J.A.; Benveniste, E.N. PERK-dependent activation of JAK1 and STAT3 contributes to endoplasmic reticulum stress-induced inflammation. Mol. Cell Biol. 2014, 34, 3911-3925. [CrossRef]

69. Chen, H.; O’Reilly, E.J.; Schwarzschild, M.A.; Ascherio, A. Peripheral inflammatory biomarkers and risk of Parkinson's disease. Am. J. Epidemiol. 2008, 167, 90-95. [CrossRef]

70. Lee, E.J.; Woo, M.S.; Moon, P.G.; Baek, M.C.; Choi, I.Y.; Kim, W.K.; Junn, E.; Kim, H.S. Alpha-synuclein activates microglia by inducing the expressions of matrix metalloproteinases and the subsequent activation of protease-activated receptor-1. J. Immunol. 2010, 185, 615-623. [CrossRef]

71. Qin, H.; Buckley, J.A.; Li, X.; Liu, Y.; Fox, T.H.; Meares, G.P.; Yu, H.; Yan, Z.; Harms, A.S.; Li, Y.; et al. Inhibition of the JAK/STAT Pathway Protects Against $\alpha$-Synuclein-Induced Neuroinflammation and Dopaminergic Neurodegeneration. J. Neurosci. 2016, 36, 5144-5159. [CrossRef] [PubMed] 
72. Huang, Z.; Wang, Y.; Hu, G.; Zhou, J.; Mei, L.; Xiong, W.C. YAP Is a Critical Inducer of SOCS3, Preventing Reactive Astrogliosis. Cereb. Cortex 2016, 26, 2299-2310. [CrossRef] [PubMed]

73. Piccolo, S.; Dupont, S.; Cordenonsi, M. The biology of YAP/TAZ: hippo signaling and beyond. Physiol. Rev. 2014, 94, 1287-1312. [CrossRef] [PubMed]

74. Blunt, J.W.; Carroll, A.R.; Copp, B.R.; Davis, R.A.; Keyzers, R.A.; Prinsep, M.R. Marine natural products. Nat. Prod. Rep. 2018, 35, 8-53. [CrossRef]

75. Correa, I.; Drews, P.; Botelho, S.; de Souza, M.S.; Tavano, V.M. Deep Learning for Microalgae Classification. In Proceedings of the 16th IEEE International Conference on Machine Learning and Applications (ICMLA), Cancun, Mexico, 18-21 December 2017. [CrossRef]

76. Peng, Y.; Hu, J.; Yang, B.; Lin, X.-P.; Zhou, X.-F.; Yang, X.-W.; Liu, Y. Chemical composition of seaweeds, Seaweed Sustainability: Food and Non-Food Applications; Academic Press: Salt Lake City, USA, 2015; pp. 79-124.

77. Goo, B.G.; Baek, G.; Choi, D.J.; Park, Y.I.; Synytsya, A.; Bleha, R.; Seong, D.H.; Lee, C.G.; Park, J.K. Characterization of a renewable extracellular polysaccharide from defatted microalgae Dunaliella tertiolecta. Bioresour. Technol. 2013, 129, 343-350. [CrossRef] [PubMed]

78. Kurniawati, H.A.; Ismadji, S.; Liu, J.C. Microalgae harvesting by flotation using natural saponin and chitosan. Bioresour. Technol. 2014, 166, 429-434. [CrossRef]

79. Zhou, R.; Shi, X.Y.; Bi, D.C.; Fang, W.S.; Wei, G.B.; Xu, X. Alginate-Derived Oligosaccharide Inhibits Neuroinflammation and Promotes Microglial Phagocytosis of $\beta$-Amyloid. Mar. Drugs 2015, 13, 5828-5846. [CrossRef]

80. O'Sullivan, L.; Murphy, B.; McLoughlin, P.; Duggan, P.; Lawlor, P.G.; Hughes, H.; Gardiner, G.E. Prebiotics from marine macroalgae for human and animal health applications. Mar. Drugs 2010, 8, 2038-2064. [CrossRef]

81. Rea, K.; Dinan, T.G.; Cryan, J.F. The microbiome: A key regulator of stress and neuroinflammation. Neurobiol. Stress 2016, 4, 23-33. [CrossRef]

82. Wang, H.D.; Chen, C.C.; Huynh, P.; Chang, J.S. Exploring the potential of using algae in cosmetics. Bioresour. Technol. 2015, 184, 355-362. [CrossRef]

83. Yun, E.J.; Choi, I.G.; Kim, K.H. Red macroalgae as a sustainable resource for bio-based products. Trends Biotechnol. 2015, 33, 247-249. [CrossRef] [PubMed]

84. Chen, H.; Yan, X.; Zhu, P.; Lin, J. Antioxidant activity and hepatoprotective potential of agaro-oligosaccharides in vitro and in vivo. Nutr. J. 2006, 5, 31. [CrossRef] [PubMed]

85. Enoki, T.; Okuda, S.; Kudo, Y.; Takashima, F.; Sagawa, H.; Kato, I. Oligosaccharides from agar inhibit pro-inflammatory mediator release by inducing heme oxygenase 1. Biosci. Biotechnol. Biochem. 2010, 74, 766-770. [CrossRef] [PubMed]

86. Bin, B.H.; Kim, S.T.; Bhin, J.; Lee, T.R.; Cho, E.G. The Development of Sugar-Based Anti-Melanogenic Agents. Int. J. Mol. Sci 2016, 17, 583. [CrossRef] [PubMed]

87. Fernando, I.P.S.; Sanjeewa, K.K.A.; Samarakoon, K.W.; Lee, W.W.; Kim, H.S.; Kang, N.; Ranasinghe, P.; Lee, H.S.; Jeon, Y.J. A fucoidan fraction purified from Chnoospora minima; a potential inhibitor of LPS-induced inflammatory responses. Int. J. Biol Macromol. 2017, 104, 1185-1193. [CrossRef] [PubMed]

88. Raposo, M.F.; de Morais, R.M.; Bernardo de Morais, A.M. Bioactivity and applications of sulphated polysaccharides from marine microalgae. Mar. Drugs 2013, 11, 233-252. [CrossRef] [PubMed]

89. Ho, S.H.; Chen, C.Y.; Chang, J.S. Effect of light intensity and nitrogen starvation on CO2 fixation and lipid/carbohydrate production of an indigenous microalga Scenedesmus obliquus CNW-N. Bioresour. Technol. 2012, 113, 244-252. [CrossRef]

90. Cheng, Y.-S.; Zheng, Y.; Labavitch, J.M.; VanderGheynst, J.S. The impact of cell wall carbohydrate composition on the chitosan flocculation of Chlorella. Process. Biochem. 2011, 46, 1927-1933. [CrossRef]

91. Kumari, P.; Kumar, M.; Reddy, C.R.K. Algal lipids, fatty acids and sterols. Functional ingredients from algae for foods and nutraceuticals; Woodhead Publishing: Cambridge, UK, 2013; pp. 87-134.

92. Manuelli, M.; Della Guardia, L.; Cena, H. Enriching Diet with n-3 PUFAs to Help Prevent Cardiovascular Diseases in Healthy Adults: Results from Clinical Trials. Int. J. Mol. Sci 2017, 18, 1552. [CrossRef]

93. Layé, S.; Nadjar, A.; Joffre, C.; Bazinet, R.P. Anti-Inflammatory Effects of Omega-3 Fatty Acids in the Brain: Physiological Mechanisms and Relevance to Pharmacology. Pharm. Rev. 2018, 70, 12-38. [CrossRef]

94. Van Ginneken, V.J.; Helsper, J.P.; de Visser, W.; van Keulen, H.; Brandenburg, W.A. Polyunsaturated fatty acids in various macroalgal species from North Atlantic and tropical seas. Lipids Health Dis. 2011, 10, 104. [CrossRef] [PubMed] 
95. Santos, M.A.Z.; Colepicolo, P.; Pupo, D.; Fujii, M.T.; de Pereira, C.M.P.; Mesko, M.F. Antarctic red macroalgae: a source of polyunsaturated fatty acids. J. Appl. Phycol. 2017, 29, 759-767. [CrossRef]

96. Jung, H.A.; Jin, S.E.; Ahn, B.R.; Lee, C.M.; Choi, J.S. Anti-inflammatory activity of edible brown alga Eisenia bicyclis and its constituents fucosterol and phlorotannins in LPS-stimulated RAW264.7 macrophages. Food Chem. Toxicol. 2013, 59, 199-206. [CrossRef] [PubMed]

97. Sun, Y.; Lin, Y.; Cao, X.; Xiang, L.; Qi, J. Sterols from Mytilidae show anti-aging and neuroprotective effects via anti-oxidative activity. Int. J. Mol. Sci 2014, 15, 21660-21673. [CrossRef] [PubMed]

98. Chen, H.; Han, C.; Wu, J.; Liu, X.; Zhan, Y.; Chen, J.; Chen, Y.; Gu, R.; Zhang, L.; Chen, S.; et al. Accessible Method for the Development of Novel Sterol Analogues with Dipeptide-like Side Chains That Act as Neuroinflammation Inhibitors. ACS Chem. Neurosci. 2016, 7, 305-315. [CrossRef] [PubMed]

99. Harnedy, P.A.; FitzGerald, R.J. BIOACTIVE PROTEINS, PEPTIDES, AND AMINO ACIDS FROM MACROALGAE(1). J. Phycol. 2011, 47, 218-232. [CrossRef]

100. Aydın, A.F.; Çoban, J.; Doğan-Ekici, I.; Betül-Kalaz, E.; Doğru-Abbasoğlu, S.; Uysal, M. Carnosine and taurine treatments diminished brain oxidative stress and apoptosis in D-galactose aging model. Metab Brain Dis. 2016, 31, 337-345. [CrossRef]

101. Korhonen, H.; Pihlanto, A. Bioactive peptides: production and functionality. Int. Dairy J. 2006, 16, 945-960. [CrossRef]

102. Vanderlei, E.S.; Patoilo, K.K.; Lima, N.A.; Lima, A.P.; Rodrigues, J.A.; Silva, L.M.; Lima, M.E.; Lima, V.; Benevides, N.M. Antinociceptive and anti-inflammatory activities of lectin from the marine green alga Caulerpa cupressoides. Int. Immunopharmacol. 2010, 10, 1113-1118. [CrossRef]

103. Silva, L.M.; Lima, V.; Holanda, M.L.; Pinheiro, P.G.; Rodrigues, J.A.; Lima, M.E.; Benevides, N.M. Antinociceptive and anti-inflammatory activities of lectin from marine red alga Pterocladiella capillacea. Biol. Pharm Bull. 2010, 33, 830-835. [CrossRef]

104. Coelho, L.C.; Silva, P.M.; Lima, V.L.; Pontual, E.V.; Paiva, P.M.; Napoleão, T.H.; Correia, M.T. Lectins, Interconnecting Proteins with Biotechnological/Pharmacological and Therapeutic Applications. Evid Based Complement. Altern. Med. 2017, 2017, 1594074. [CrossRef]

105. Fan, X.; Bai, L.; Zhu, L.; Yang, L.; Zhang, X. Marine algae-derived bioactive peptides for human nutrition and health. J. Agric. Food Chem. 2014, 62, 9211-9222. [CrossRef] [PubMed]

106. Eom, S.H.; Kim, Y.M.; Kim, S.K. Antimicrobial effect of phlorotannins from marine brown algae. Food Chem. Toxicol 2012, 50, 3251-3255. [CrossRef] [PubMed]

107. Corona, G.; Coman, M.M.; Guo, Y.; Hotchkiss, S.; Gill, C.; Yaqoob, P.; Spencer, J.P.E.; Rowland, I. Effect of simulated gastrointestinal digestion and fermentation on polyphenolic content and bioactivity of brown seaweed phlorotannin-rich extracts. Mol. Nutr. Food Res. 2017, 61. [CrossRef] [PubMed]

108. Montero, L.; del Pilar Sánchez-Camargo, A.; Ibáñez, E.; Gilbert-López, B. Phenolic Compounds from Edible Algae: Bioactivity and Health Benefits. Curr. Med. Chem. 2018, 25, 4808-4826. [CrossRef] [PubMed]

109. Sivagnanam, S.P.; Yin, S.; Choi, J.H.; Park, Y.B.; Woo, H.C.; Chun, B.S. Biological Properties of Fucoxanthin in Oil Recovered from Two Brown Seaweeds Using Supercritical $\mathrm{CO}_{2}$ Extraction. Mar. Drugs 2015, 13, 3422-3442. [CrossRef] [PubMed]

110. Mikami, K.; Hosokawa, M. Biosynthetic pathway and health benefits of fucoxanthin, an algae-specific xanthophyll in brown seaweeds. Int. J. Mol. Sci. 2013, 14, 13763-13781. [CrossRef] [PubMed]

111. Peng, J.; Yuan, J.P.; Wu, C.F.; Wang, J.H. Fucoxanthin, a marine carotenoid present in brown seaweeds and diatoms: metabolism and bioactivities relevant to human health. Mar. Drugs 2011, 9, 1806-1828. [CrossRef] [PubMed]

112. Gateau, H.; Solymosi, K.; Marchand, J.; Schoefs, B. Carotenoids of Microalgae Used in Food Industry and Medicine. Mini. Rev. Med. Chem. 2017, 17, 1140-1172. [CrossRef]

113. Eggersdorfer, M.; Wyss, A. Carotenoids in human nutrition and health. Arch. Biochem. Biophys 2018, 652, 18-26. [CrossRef]

114. Pangestuti, R.; Vo, T.S.; Ngo, D.H.; Kim, S.K. Fucoxanthin ameliorates inflammation and oxidative reponses in microglia. J. Agric. Food Chem. 2013, 61, 3876-3883. [CrossRef]

115. Kim, Y.H.; Koh, H.K.; Kim, D.S. Down-regulation of IL-6 production by astaxanthin via ERK-, MSK-, and NF-kB-mediated signals in activated microglia. Int. Immunopharmacol. 2010, 10, 1560-1572. [CrossRef] [PubMed] 
116. Gaysinski, M.; Ortalo-Magné, A.; Thomas, O.P.; Culioli, G. Extraction, Purification, and NMR Analysis of Terpenes from Brown Algae. Methods Mol. Biol. 2015, 1308, 207-223. [CrossRef] [PubMed]

117. Yang, P.; Liu, D.Q.; Liang, T.J.; Li, J.; Zhang, H.Y.; Liu, A.H.; Guo, Y.W.; Mao, S.C. Bioactive constituents from the green alga Caulerpa racemosa. Bioorg. Med. Chem. 2015, 23, 38-45. [CrossRef] [PubMed]

118. Kirkley, K.S.; Popichak, K.A.; Afzali, M.F.; Legare, M.E.; Tjalkens, R.B. Microglia amplify inflammatory activation of astrocytes in manganese neurotoxicity. J. Neuroinflammation 2017, 14, 99. [CrossRef] [PubMed]

119. Heneka, M.T.; Carson, M.J.; El Khoury, J.; Landreth, G.E.; Brosseron, F.; Feinstein, D.L.; Jacobs, A.H.; Wyss-Coray, T.; Vitorica, J.; Ransohoff, R.M.; et al. Neuroinflammation in Alzheimer's disease. Lancet Neurol. 2015, 14, 388-405. [CrossRef]

120. Pangestuti, R.; Kim, S.K. Neuroprotective effects of marine algae. Mar. Drugs 2011, 9, 803-818. [CrossRef]

121. Lee, J.Y.; Lee, M.S.; Choi, H.J.; Choi, J.W.; Shin, T.; Woo, H.C.; Kim, J.I.; Kim, H.R. Hexane fraction from Laminaria japonica exerts anti-inflammatory effects on lipopolysaccharide-stimulated RAW 264.7 macrophages via inhibiting NF-kappaB pathway. Eur. J. Nutr. 2013, 52, 409-421. [CrossRef]

122. Khan, M.N.; Lee, M.C.; Kang, J.Y.; Park, N.G.; Fujii, H.; Hong, Y.K. Effects of the brown seaweed Undaria pinnatifida on erythematous inflammation assessed using digital photo analysis. Phytother. Res. 2008, 22, 634-639. [CrossRef]

123. Kang, J.Y.; Khan, M.N.; Park, N.H.; Cho, J.Y.; Lee, M.C.; Fujii, H.; Hong, Y.K. Antipyretic, analgesic, and anti-inflammatory activities of the seaweed Sargassum fulvellum and Sargassum thunbergii in mice. J. Ethnopharmacol. 2008, 116, 187-190. [CrossRef]

124. Kim, S.; Kim, J.I.; Choi, J.W.; Kim, M.; Yoon, N.Y.; Choi, C.G.; Choi, J.S.; Kim, H.R. Anti-inflammatory effect of hexane fraction from Myagropsis myagroides ethanolic extract in lipopolysaccharide-stimulated BV-2 microglial cells. J. Pharm. Pharm. 2013, 65, 895-906. [CrossRef] [PubMed]

125. Kim, S.; Lee, M.S.; Lee, B.; Gwon, W.G.; Joung, E.J.; Yoon, N.Y.; Kim, H.R. Anti-inflammatory effects of sargachromenol-rich ethanolic extract of Myagropsis myagroides on lipopolysaccharide-stimulated BV-2 cells. Bmc Complement. Altern Med. 2014, 14, 231. [CrossRef]

126. Aisya, G.S.; Ching, T.S.; Yee, G.S. Antioxidative, Anticholinesterase and Anti-Neuroinflammatory Properties of Malaysian Brown and Green Seaweeds. Int. J. Ind. Manuf. Eng. 2014, 8, 895-906.

127. Craig, L.A.; Hong, N.S.; McDonald, R.J. Revisiting the cholinergic hypothesis in the development of Alzheimer's disease. Neurosci. Biobehav. Rev. 2011, 35, 1397-1409. [CrossRef] [PubMed]

128. Hoong, W.C.; John, I.; Yee, G.S.; Ling, C.E.W.; Ching, T.S.; Moi, P.S.; Aisya, G.S.; Tiong, Y.; Irvine, G.A. Fucosterol inhibits the cholinesterase activities and reduces the release of pro-inflammatory mediators in lipopolysaccharide and amyloid-induced microglial cells. J. Appl. Phycol. 2018, 30, 3261-3270.

129. Jung, W.K.; Heo, S.J.; Jeon, Y.J.; Lee, C.M.; Park, Y.M.; Byun, H.G.; Choi, Y.H.; Park, S.G.; Choi, I.W. Inhibitory effects and molecular mechanism of dieckol isolated from marine brown alga on COX-2 and iNOS in microglial cells. J. Agric. Food Chem. 2009, 57, 4439-4446. [CrossRef] [PubMed]

130. Lee, S.; Youn, K.; Kim, D.H.; Ahn, M.R.; Yoon, E.; Kim, O.Y.; Jun, M. Anti-Neuroinflammatory Property of Phlorotannins from Ecklonia cava on A $325-35-$ Induced Damage in PC12 Cells. Mar. Drugs 2019, $17,7$. [CrossRef] [PubMed]

131. Kim, M.; Li, Y.X.; Dewapriya, P.; Ryu, B.; Kim, S.K. Floridoside suppresses pro-inflammatory responses by blocking MAPK signaling in activated microglia. BMB Rep. 2013, 46, 398-403. [CrossRef]

132. Heo, S.J.; Yoon, W.J.; Kim, K.N.; Ahn, G.N.; Kang, S.M.; Kang, D.H.; Affan, A.; Oh, C.; Jung, W.K.; Jeon, Y.J. Evaluation of anti-inflammatory effect of fucoxanthin isolated from brown algae in lipopolysaccharide-stimulated RAW 264.7 macrophages. Food Chem. Toxicol. 2010, 48, 2045-2051. [CrossRef]

133. Lin, T.Y.; Lu, C.W.; Wang, S.J. Astaxanthin inhibits glutamate release in rat cerebral cortex nerve terminals via suppression of voltage-dependent $\mathrm{Ca}^{2+}$ entry and mitogen-activated protein kinase signaling pathway. $J$. Agric. Food Chem. 2010, 58, 8271-8278. [CrossRef]

134. Wu, H.; Niu, H.; Shao, A.; Wu, C.; Dixon, B.J.; Zhang, J.; Yang, S.; Wang, Y. Astaxanthin as a Potential Neuroprotective Agent for Neurological Diseases. Mar. Drugs 2015, 13, 5750-5766. [CrossRef] [PubMed]

135. Wu, D.; Xu, H.; Chen, J.; Zhang, L. Effects of Astaxanthin Supplementation on Oxidative Stress. Int. J. Vitam. Nutr. Res. 2019, 1-16. [CrossRef] [PubMed]

136. Balietti, M.; Giannubilo, S.R.; Giorgetti, B.; Solazzi, M.; Turi, A.; Casoli, T.; Ciavattini, A.; Fattorettia, P. The effect of astaxanthin on the aging rat brain: gender-related differences in modulating inflammation. J. Sci. Food Agric. 2016, 96, 4295. [CrossRef] [PubMed] 
137. Krogh, J.; Benros, M.E.; Jørgensen, M.B.; Vesterager, L.; Elfving, B.; Nordentoft, M. The association between depressive symptoms, cognitive function, and inflammation in major depression. Brain Behav. Immun. 2014, 35, 70-76. [CrossRef] [PubMed]

138. Miller, A.H.; Raison, C.L. The role of inflammation in depression: from evolutionary imperative to modern treatment target. Nat. Rev. Immunol. 2015, 16, 22-34. [CrossRef] [PubMed]

139. Zhang, X.S.; Zhang, X.; Wu, Q.; Li, W.; Wang, C.X.; Xie, G.B.; Zhou, X.M.; Shi, J.X.; Zhou, M.L. Astaxanthin offers neuroprotection and reduces neuroinflammation in experimental subarachnoid hemorrhage. J. Surg. Res. 2014, 192, 206-213. [CrossRef] [PubMed]

140. Lee, J.C.; Hou, M.F.; Huang, H.W.; Chang, F.R.; Yeh, C.C.; Tang, J.Y.; Chang, H.W. Marine algal natural products with anti-oxidative, anti-inflammatory, and anti-cancer properties. Cancer Cell Int. 2013, 13, 55. [CrossRef]

141. Choi, J.Y.; Hwang, C.J.; Lee, H.P.; Kim, H.S.; Han, S.B.; Hong, J.T. Inhibitory effect of ethanol extract of Nannochloropsis oceanica on lipopolysaccharide-induced neuroinflammation, oxidative stress, amyloidogenesis and memory impairment. Oncotarget 2017, 8, 45517-45530. [CrossRef]

142. Xiang, Y.; Meng, S.; Wang, J.; Li, S.; Liu, J.; Li, H.; Li, T.; Song, W.; Zhou, W. Two novel DNA motifs are essential for BACE1 gene transcription. Sci Rep. 2014, 4, 6864. [CrossRef]

143. Smith, A.M.; Gibbons, H.M.; Dragunow, M. Valproic acid enhances microglial phagocytosis of amyloid-beta(1-42). Neuroscience 2010, 169, 505-515. [CrossRef]

144. Guo, X.; Xin, X.; Gan, L.; Nie, Q.; Geng, M. Determination of the accessibility of acidic oligosaccharide sugar chain to blood-brain barrier using surface plasmon resonance. Biol. Pharm. Bull. 2006, 29, 60-63. [CrossRef] [PubMed]

145. Cui, Y.Q.; Jia, Y.J.; Zhang, T.; Zhang, Q.B.; Wang, X.M. Fucoidan protects against lipopolysaccharide-induced rat neuronal damage and inhibits the production of proinflammatory mediators in primary microglia. CNS. Neurosci. 2012, 18, 827-833. [CrossRef] [PubMed]

146. Rafiquzzaman, S.M.; Kim, E.Y.; Lee, J.M.; Mohibbullah, M.; Alam, M.B.; Moon, I.S.; Kim, J.-M.; Kong, I.-S. Anti-Alzheimers and anti-inflammatory activities of a glycoprotein purified from the edible brown alga Undaria pinnatifida. Food Res. Int. 2015, 77, 118-124.

147. Ryan, S.; O'Gorman, D.M.; Nolan, Y.M. Evidence that the marine-derived multi-mineral Aquamin has anti-inflammatory effects on cortical glial-enriched cultures. Phytother. Res. 2011, 25, 765-767. [CrossRef] [PubMed] 